\title{
The Enzymic Activity of the Outer Shell of Lactobacillus arabinosus
}

\author{
By H. A. COLE and D. E. HUGHES \\ Medical Research Council Unit for Research in Cell Metabolism, \\ Biochemistry Department, Oxford, and the Microbiology Department, \\ University College, Cardiff
}

(Received 29 December 1964)

\begin{abstract}
SUMMARY
Preparations of the outer shell of Lactobacillus arabinosus were made by crushing the bacteria in a Hughes press and removing the cytoplasm by washing and centrifugation. Such preparations had none of the enzymes associated with flavin-mediated oxidation; they had consistently adenosine triphosphatase (ATPase) activity. The kinetics and other properties of this enzyme were studied. The evidence suggested that the enzyme was bound to the cytoplasmic membrane, the bulk of which appeared to be within the cell wall. The preparation was thus similar to that from obligate facultative aerobes and which, in contrast to the preparations from lactobacilli, contained enzymes associated with oxygen utilization mediated by the cytochrome hydrogen transport system. The bound ATPase had an optimum at pH 6.0 and was not markedly inhibited by ouabain or oligomycin: it was stimulated by 2,4-dinitrophenol. It was thus different from ATPase associated with ion transport but similar to that from mitochondrial membranes. There was no nucleotide pyrophosphorylase activity in the preparation but other nucleotide triphosphates and diphosphates and some inorganic phosphates were hydrolysed but at slower rates than was ATP.
\end{abstract}

\section{INTRODUCTION}

In previous work (Hughes, 1962 ; Francis, Hughes, Kornberg \& Phizackerly, 1963) it was shown that the outer shells of many aerobic bacteria may be prepared by crushing the organisms in a Hughes (1951) press and removing the cytoplasmic contents by washing and centrifugation. Such preparations have been called cellwall membranes because they have the form and chemical constituents of the cell wall and also the phospholipid components and enzymic activities associated with the cytoplasmic membrane. In the present work similar preparations were made by the same method from Lactobacillus arabinosus. This organism normally does not use oxygen as a final hydrogen acceptor for energy (ATP) production but can utilize oxygen to oxidize several substrates by flavin enzymes which were thought to be soluble; the exception was the pyruvate oxidase which was particulate (Strittmatter, 1959). However, the enzyme preparations from $L$. arabinosus were made by prolonged ultrasonic treatment, a process which comminutes the outer shells of bacteria into fine fragments and solubilizes some enzymes associated with them. The cell-wall membranes were found not to contain these flavin enzymes which were all in the soluble fractions, but did contain an adenosine triphosphatase 
(ATPase). The properties of this enzyme have now been investigated. The evidence presented here supports the view that the ATPase is bound to the cytoplasmic membrane. While this work was in progress an ATPase has been found in similar preparations from the obligate anaerobes Clostridium welchii and C. sporogenes. It was also present in membrane preparations 'ghosts' from spheroplasts of this latter organism (Galli \& Hughes, 1965). The enzyme is also present in membrane preparations and cell-wall membranes of aerobes. So far it has not been possible to assign a role to this membrane-bound bacterial ATPase.

\section{METHODS}

Growth of Lactobacillus arabinosus. L. arabinosus strain 17-5 was grown in a medium (Barton-Wright, 1952) containing amino acids, B-group vitamins, glucose and salts. In 1 l.; $20 \mathrm{~g}$. Oxoid tryptone; $6 \mathrm{~g}$. Oxoid yeast extract; $20 \mathrm{~g}$. glucose; 10 g. sodium acetate; 4.5 g. $\mathrm{KH}_{2} \mathrm{PO}_{4} ; 26 \mathrm{ml}$. N-NaOH; 5 ml. essential salts solution; 4 g. $\mathrm{MgSO}_{4} \cdot 7 \mathrm{H}_{2} \mathrm{O} ; 0 \cdot 1 \mathrm{~g} . \mathrm{MnSO}_{4} \cdot 4 \mathrm{H}_{2} \mathrm{O} ; 0 \cdot 04 \mathrm{~g}$. anhydrous $\mathrm{FeCl}_{3}$ in $100 \mathrm{ml}$. dilute

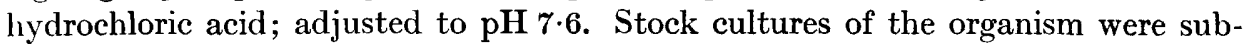
cultured every 2 weeks, grown at $30^{\circ}$ and stored at $2^{\circ}$.

Large quantities of the organism were grown in $10 \mathrm{l}$. bottles nearly full of medium which were inoculated with a growing culture. After incubation for 18-20 hr, when the medium had become about $\mathrm{pH} 4 \cdot 5$, the bacteria were collected with a Sharples continuous centrifuge. The bacteria were then washed well with $0 \cdot 1 \mathrm{M}$-tris + maleate buffer ( $\mathrm{pH} 7$ ), centrifuged again and resuspended in a small volume of this buffer. The average yield was $7 \mathrm{~g}$. wet wt. bacteria/l. medium.

Preparation of cell-wall membranes. In a typical preparation, about 60 g. wetweight bacteria, suspended in a small volume of $0 \cdot 1 \mathrm{M}$-tris + maleate buffer $(\mathrm{pH} 7)$, were crushed at $-25^{\circ}$ in a Hughes (1951) press. The material obtained was thawed, suspended in 2 vol. of a mixture of equal volumes of $0.1 \mathrm{M}$-tris +maleate buffer $(\mathrm{pH} 7)$ and $0.9 \% \mathrm{NaCl}$ in a loose-fitting glass homogenizer and incubated for $30 \mathrm{~min}$. at about $2^{\circ}$ with $100 \mu \mathrm{g}$. deoxyribonuclease to decrease the high viscosity of the preparation and facilitate emptying of the broken bacteria. The degree of breakage was judged at this stage by electron microscopy (Pl. 1, fig. I). The preparation was then centrifuged at $30,000 \mathrm{~g}$ at $2^{\circ}$ for $30 \mathrm{~min}$. and separated into a supernatant fraction and a solid residue. The residue consisted of two layers, the uppermost being composed of cell-wall membranes (CWM). This layer was removed by using a curved spatula and resuspended in buffer saline mixture and centrifuged at $30,000 \mathrm{~g}$ for $30 \mathrm{~min}$. twice more. The material thus obtained was usually equivalent to about 1-3 g. dry wt. This material was resuspended in about $75 \mathrm{ml}$. of $0 \cdot 1 \mathrm{M}$ tris + maleate buffer $(\mathrm{pH} 7)$ and stored at $2^{\circ}$. The preparation then consisted of electron-transparent hulls of bacteria, containing very little electron-dense material (Pl. 1, fig. 2).

An attempt was made to produce cell-wall membranes by using a French press (Milner, Lawrence \& French, 1950) in which a $20 \%(\mathrm{v} / \mathrm{v})$ suspension of bacteria in buffer at $4^{\circ}$ was broken by liquid shear at pressures of $15 \times 10^{3} \mathrm{lb}$./sq.in. Electron microscopy showed that a suspension had to be passed through the French press at least six times to produce the same degree of breakage as was produced by one treatment in the Hughes press. This resulted in further comminution of the cell-wall membranes and so the method was not used further. 
Further fragmentation of the cell-wall membranes by ultrasonic treatment. The suspension $(25 \mathrm{ml}$.) of washed cell-wall membranes (about $0.2 \mathrm{~g}$. wet wt./ml.) in $0 \cdot 1 \mathrm{M}$-tris + maleate buffer in a $100 \mathrm{ml}$. beaker cooled in ice was disrupted by ultrasonic treatment with a $600 \mathrm{~W}$. Mullard magnetostricter oscillator operating at a power level $6.9 \mathrm{~V}$. at a setting of $65 / 100$ for $45 \mathrm{~min}$. Electron microscopy showed that the cell-wall membranes after this treatment were considerably fragmented (Pl. 1, fig. 3). The solid fragments were removed by centrifugation at $100,000 \mathrm{~g}$ for $90 \mathrm{~min}$. at $0^{\circ}$ in a Spinco model $\mathrm{L}$ preparative ultracentrifuge. The clear supernatant fluid was separated from the residue and the latter resuspended in $25 \mathrm{ml}$. of the original buffer.

Electron microscopy. Cell fractions for routine work were dried on to Formvarcovered grids and examined by transmission. To gain a more accurate knowledge of the shape of the particles in the fractions, the samples were fixed with $1 \%$ osmic acid and then shadowed with $40 \% \mathrm{Au}+60 \% \mathrm{Pd}$. All material was examined in an Akashi TR 50 Tronoscope at initial magnifications between 600 and 15,000.

Assays of adenosine triphosphatase activity. It was assumed that the enzyme hydrolysed ATP according to the equation: ATP $+\mathrm{H}_{2} \mathrm{O} \rightarrow \mathrm{ADP}+\mathrm{H}_{3} \mathrm{PO}_{4}$. Thus assays for either the phosphate ion or the first highly acidic hydrogen ion of $\mathrm{H}_{3} \mathrm{PO}_{4}$ both estimated the activity of the enzyme.

Assay of phosphate release. In most experiments about $15 \mathrm{mg}$. wet weight solid or $0.1 \mathrm{ml}$. of supernatant fluid were incubated at $37^{\circ}$ with ATP $(0.3-20 \mathrm{mM}) ; \mathrm{MgCl}_{2}$ at the same concentration as that of ATP; $0.5 \mathrm{ml}$. $0.1 \mathrm{M}$-tris + maleate buffer ( $\mathrm{pH} 7 \cdot 0$ ); in total volume of 1-2 ml. Incubation times varied between $15 \mathrm{~min}$. and $2 \mathrm{hr}$. After incubation the tubes were cooled to $2^{\circ}$ and $1 \mathrm{ml}$. of cold $5 \%(\mathrm{w} / \mathrm{v})$ perchloric acid added. Tubes were then centrifuged at about $5000 \mathrm{~g}$ in cooled centrifuge cups to remove precipitated protein. Duplicate samples of the supernatant fluid were added to $8 \mathrm{ml}$. water in $10 \mathrm{ml}$. graduated tubes and the inorganic phosphate estimated by the method of Fiske \& SubbaRow (1925). The reducing agent was 1-amino-2-naphthol-4-sulphonic acid, sodium sulphite and bisulphite. A blank without reagents and a standard containing $1 \mu$ mole orthophosphate were also treated with the reagents. $\boldsymbol{E}_{\mathbf{7 0 0}}$ was read in glass cuvettes in a Unicam S.P.600 spectrophotometer. The amount of phosphate was calculated from standard curves and expressed as a mean of the two samples from which the inorganic phosphate of ATP and the enzyme was deducted $(<0.2 \mu$ mole).

Assay of hydrogen-ion release. Continuous titrations were carried out at $37^{\circ}$ with $\mathrm{NaOH}$ in a Radiometer automatic titrator, with a combined calomel and hydrogen electrode. The initial volume of cell-wall membrane and $\mathrm{MgCl}_{2}$ was $1 \mathrm{ml}$; no buffer was added to the incubation mixture, which was kept constant at $\mathrm{pH} \mathbf{7 \cdot 4}$. This is slightly higher than the optimum $\mathrm{pH}$ value, but consistent results were not obtained at $\mathrm{pH} 6 \cdot 0$.

Typical mixtures contained $0 \cdot 4 \mathrm{~mm}-\mathrm{MgCl}_{2} ; 50 \mathrm{mg}$. wet weight cell-wall membrane, in a total volume of $1 \mathrm{ml}$. This mixture was at about $\mathrm{pH} 6 ; 0.1 \mathrm{~N}-\mathrm{NaOH}$ was added to bring to $\mathrm{pH} 7 \cdot 4$. The mixture was kept at $37^{\circ}$ and stirred with $\mathrm{CO}_{2}$-free air. Various volumes of $0.2 \mathrm{M}$-ATP were then added to start the reaction and the microburette added sufficient $0.01 \mathrm{~N}-\mathrm{NaOH}$ to maintain the mixture at $\mathrm{pH} \mathbf{7 \cdot 4}$. The volume of $\mathrm{NaOH}$ added was recorded as a function of time; the slope of this curve was therefore proportional to the rate of reaction. 
Chemical analysis of cell fractions. Protein was estimated by the method of Lowry, Rosebrough, Farr \& Randall (1951) with the Folin-Ciocalteau reagent and measurement of the extinction $\left(E_{625}\right)$ of the blue colour in a Unicam S.P. 600 spectrophotometer. For carbohydrate analysis, fractions were hydrolysed by $4 \mathrm{~N}$-sulphuric acid at $100^{\circ}$ for $2 \mathrm{hr}$ in a sealed tube, after which insoluble material was removed by centrifugation at $5000 \mathrm{~g}$. In this supernatant fluid, total carbohydrate was estimated by the method of Dische (1929); methylpentoses by the method of Dische \& Shettles (1948) and glucosamine by a modified method of Aminoff, Morgan \& Watkins (1951), Levvy \& McAllen (1959). Deoxyribonucleic acid in the original samples was estimated by the method of Burton (1956) and ribonucleic acid in the same samples by the method of Mejbaum (1939).

Lipid was extracted with a $2+1$ mixture of redistilled chloroform + methanol and the extract washed twice with $\mathbf{0 . 5}$ vol. of water. After drying the chloroform + methanol extract with anhydrous sodium sulphate, the extract was evaporated under nitrogen and then under vacuum to dryness in weighed beakers by an infrared lamp. Samples of this anydrous material were then saponified with methanolic $(50 \%) 2 \mathrm{~N}$-potassium hydroxide solution and esterified in light petroleum $\left(40-60^{\circ}\right)$ with diazomethane in ether, then applied to a gas chromatography column, as described below.

Chromatographic methods. Nucleotides and inorganic phosphate were separated by paper chromatography by the method of Krebs \& Hems (1953).

For the chromatography of sugars, samples of carbohydrate, hydrolysed with $\mathrm{H}_{2} \mathrm{SO}_{4}$, were neutralized with saturated baryta, the barium sulphate was removed by centrifugation and the solutions evaporated to $0.5 \mathrm{ml}$. under a Magda infra-red lamp. The solvents used were phenol + water and $n$-butanol + acetic acid + water (Woiwod, 1949). A standard sugar sample was placed on each chromatogram (Putman, 1957) $m$-phenylenediamine hydrochloride was used as the developing agent (Chernick, Chaikoff \& Abraham, 1951). The relative $\boldsymbol{R}_{F}$ values used were those of Partridge \& Westall (1948).

Methyl esters of fatty acids were separated by gas chromatography in an Argon Chromatograph (Pye Co. Ltd., Cambridge). The support was acid and alkaliwashed Celite 535 (Johns-Manville Co. Ltd., London, S.W. 1). Apiezon L highvacuum grease $(10 \%)$ was the non-polar stationary phase. Samples $(0 \cdot 1 \mu 1$.$) of dry$ ester were placed on the column by the method of Renshaw \& Biran (1962). Peak areas were determined by triangulation according to Kouleman (1957). The chromatographic peaks were identified by comparison of the retention volumes with known acids and by hydrogenation and chromatography of the products.

The measurement of radioactive phosphorus. ${ }^{32} \mathrm{P}$ in solution was estimated in a conventional Geiger-Miller $10 \mathrm{ml}$. counting tube type M6 (supplied by 20th Century Electronics Ltd., Croydon, Surrey), operating at 1090 V. in a lead castle from E.R.D. Engineering Co. Ltd., Slough, Middlesex. The scaling unit was type N530 F obtained from Ekco Electronics Ltd., Southend-on-Sea, Essex.

For the measurement of radioactivity on paper chromatographs, an end-window counter operating at $1625 \mathrm{~V}$. attached to a Panex Scaling Unit type D657 was used. Radioactive phosphorus on chromatograms was measured by shielding the spot with a lead plate $2 \mathrm{~mm}$. thick with a hole $2 \mathrm{~cm} .+3 \mathrm{~cm}$. in the centre.

Chemicals. ${ }^{32} \mathrm{P}$-labelled adenosine triphosphate was made by the method of 
Glynn \& Chappell (1964). Starting with 1 me of orthophosphate, the final activity of the terminal phosphate group of the ATP was $300 \mu \mathrm{c}$; very little activity appeared in the $\beta$-phosphate group. Chromatograms indicated that some labelled $\mathbf{A D}^{32} \mathbf{P}$ was also present.

All other chemicals used were commercial preparations and were not purified unless so stated.

\section{RESULTS}

The rate of hydrolysis of ATP by the various preparations from Lactobacillus arabinosus, when measured by the formation of orthophosphate or hydrogen ions, proceeded linearly until about half the ATP was hydrolysed; the rate then decreased gradually (Fig. 1). The release of phosphate from increasing amounts of ATP

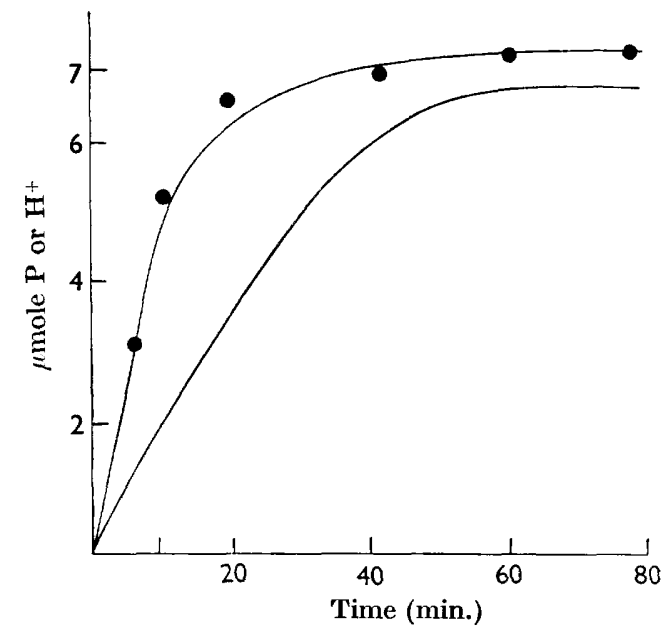

Fig. 1

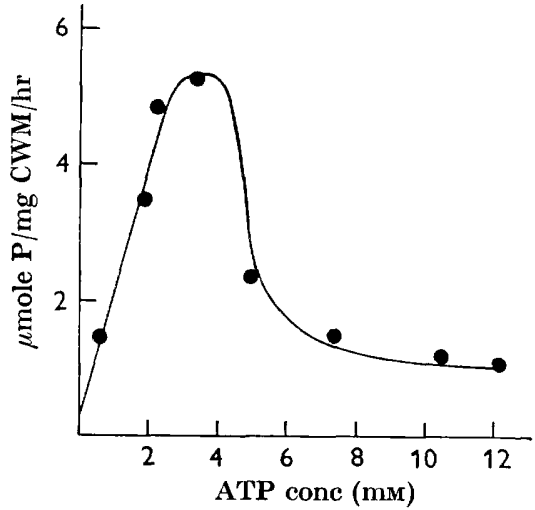

Fig. 2

Fig. 1. Reaction curves of ATPase measured by phosphate release and by titrating the $\mathrm{H}^{+}$formed. The cell-wall membrane preparation was incubated with ATP $(10 \mu \mathrm{mole})$ and phosphate released and $\mathrm{H}^{+}$formation measured as described in the text. $\longrightarrow$, Phosphate release; - $\mathrm{H}^{+}$formation.

Fig. 2. The effect of ATP concentration on phosphate release by the ATPase of cell-wall membrane preparations from Lactobacillus arabinosus 17-5. A cell-wall membrane preparation was incubated with various concentrations of ATP and the phosphate released estimated after incubation for $\mathbf{3 0} \mathrm{min}$.

with constant amounts of cell-wall membrane was measured under standard conditions. Consistent results were obtained only when the molar concentration of $\mathbf{M g}^{\mathbf{2}}$ was the same as that of ATP. When the concentrations of ATP and $\mathrm{Mg}^{2+}$ were equal, plots of phosphate release against ATP concentration increased to a maximum and then decreased (Fig. 2). This suggested that ATP at high concentration was inhibitory. The concentration of ATP needed to produce the maximum rate of hydrolysis varied with different batches of cell-wall membranes and was not proportional to their specific activity. Lineweaver-Burk plots gave an approximate value of $K_{m}$ of $3 \mathrm{~mm}$ and of $V$ of $1.7 \times 10^{5} \mu$ mole $\mathrm{P} / \mathrm{g}$. dry wt./hr. at low values of substrate concentration. Similar results were obtained when the hydrogen ion formation was measured. The rate of the initial reaction then was plotted as a function at the 
concentration of ATP and gave a $K_{m}$ of 6-12 mu. The ATPase showed a marked optimum at $\mathrm{pH} 6.0$ when measured in tris + maleate buffer (Table 1).

Hydrolysis of compounds other than ATP. Suspensions of cell-wall membrane hydrolysed ADP at $\mathbf{2 0 - 3 0 \%}$ of the rate of that of low concentrations of ATP. No maximum or minimum was observed in the curve of phosphate release against concentrations of ADP up to $16 \mathrm{~mm}$ (Table 2). The value of $K_{m}$ was $12 \mathrm{~mm}$ and $V$ was $1 \times 10^{4} \mu \mathrm{mole} \mathrm{P} / \mathrm{g}$. dry wt. cell-wall membrane/hr. To test that the same enzyme was acting on the two adenine nucleotides, equal concentrations of ATP and ADP alone and mixed were incubated with cell-wall membrane. The release of phosphate was not additive; the release from ATP with ADP was less than with ADP alone. This suggests that the same enzyme hydrolyses both ATP and ADP.

Table 1. Variation with $p H$ value of ATPase activity of cell-wall membrane preparations from Lactobacillus arabinosus 17-5

Tubes contained $0.4 \mathrm{ml}$. tris + maleate buffer (pH 7); $0.1 \mathrm{ml}$. 50 $\mu$ mole ATP $/ \mathrm{ml}$; $0.1 \mathrm{ml}$. $50 \mu$ mole $\mathrm{MgCl}_{2} / \mathrm{ml}$; ; cell-wall membrane (equiv. $15 \mathrm{mg}$. dry wt.). Measured amounts of $0.2 \mathrm{M}$-acetic acid or sodium hydroxide were added to bring the mixtures to between $\mathrm{pH} 4.6$ and 10 as measured on a $\mathrm{pH}$ meter. The $\mathrm{pH}$ value of control tubes without enzyme or ATP was adjusted similarly. The tubes were then incubated at $37^{\circ}$ for 20 min. and phosphate was determined as described previously.

$\begin{array}{cc}\begin{array}{c}\text { pH value of mixture } \\ \text { before incubation }\end{array} & \begin{array}{c}\text { Phosphate release } \\ (\mu \text { mole P/g. dry wt. } \\ \text { cell-wall membranes } / \text { hr. })\end{array} \\ 4 \cdot 6 & 880 \\ 5 \cdot 1 & 2080 \\ 5 \cdot 6 & 2460 \\ 6 \cdot 2 & 2500 \\ 6 \cdot 8 & 2300 \\ 7 \cdot 5 & 1690 \\ 7 \cdot 8 & 1870 \\ 8 \cdot 4 & 1750 \\ 9 \cdot 0 & 1380 \\ 10 & 1300\end{array}$

Table 2. The effect of ADP concentration on the rate of hydrolysis of adenosine diphosphate by cell-wall membranes

ADP at various concentrations was incubated under the usual conditions and phosphate release estimated as described in the text.

$\begin{array}{cc}\text { ADP concentration } & \begin{array}{c}\text { Phosphate release } \\ (\mathrm{mm})\end{array} \\ \begin{array}{c}(\mu \text { mole P/g. dry wt. } \\ \text { cell-wall membranes })\end{array} \\ 4 \cdot 0 & 180 \\ 6 \cdot 0 & 300 \\ 8 \cdot 0 & 350 \\ 9 \cdot 0 & 470 \\ 12 \cdot 0 & 590 \\ 13 \cdot 5 & 980\end{array}$

To estimate the effect of released ADP on the value of $K_{m}$ found for the hydrolysis of ATP, various amounts of ATP were incubated with cell-wall membrane for various times up to $40 \mathrm{~min}$. The value of $\boldsymbol{K}_{m}$ for each time was found by a Lineweaver-Burk plot. The straight lines produced in each case all cut the $x$-axis at the same point, giving a value of $K_{m}$ of about $10 \mathrm{~mm}$. Thus increasing concentrations of 
ADP produced by the hydrolysis of ATP had no appreciable effect on the value of $\boldsymbol{K}_{m}$ found by this method.

Suspensions of cell-wall membrane had no effect when incubated with adenosine monophosphate, other nucleoside diphosphates, sugar phosphates and NAD, at the times and concentrations normally used with ATP. All the nucleoside triphosphates tested were hydrolysed at a slow rate by the cell-wall membrane. Inosine triphosphate was the most rapidly attacked: the rate of hydrolysis was $50 \%$ of that of ATP under the same conditions (Table 3).

\title{
Table 3. The hydrolysis of nucleotide phosphates by cell-wall membrane preparations from Lactobacillus arabinosus 17-5
}

\begin{abstract}
Tubes contained 0.47 and $\mathbf{1 . 4 1} \mathrm{mm}$ nucleotides. Comparison tubes held similar concentrations of ATP and ADP, and a similar concentration of $\mathrm{Mg}^{2+} ; 20 \mathrm{mg}$. wet wt. cell-wall membrane preparation; $0.5 \mathrm{ml}$. 0.1 $\mathrm{M}$-tris + maleate buffer $(\mathrm{pH} 7$ ); total volume $1.2 \mathrm{ml}$. The tubes were incubated at $37^{\circ}$ for $1 \mathrm{hr}$ and phosphate was determined in the usual way, in duplicate. The amount of phosphate released is expressed after the deduction of blanks without cell-wall membrane or nucleotide.
\end{abstract}

$\begin{array}{lcc}\text { Nucleotide } & \begin{array}{c}\text { Nucleotide conc. } \\ (\mathbf{0} \cdot \mathbf{4 7} \mathrm{mM})\end{array} & \begin{array}{c}\text { Nucleotide conc. } \\ (\mathbf{1} \cdot 41 \mathrm{mM})\end{array} \\ \text { Adenosine monophosphate } & \mathbf{0} & 0 \\ \text { Adenosine diphosphate } & \mathbf{2 7} & \mathbf{3 2} \\ \text { Cytidine diphosphate } & 0 & 0 \\ \text { Inosine diphosphate } & 0 & 0 \\ \text { Uridine diphosphate } & 0 & 0 \\ \text { Guanosine diphosphate } & 0 & 0 \\ \text { Cytidine triphosphate } & 18 & \mathbf{1 5} \\ \text { Inosine triphosphate } & 42 & \mathbf{5 7} \\ \text { Guanosine triphosphate } & 32 & \mathbf{4 6} \\ \text { Thymidine triphosphate } & 40 & \mathbf{2 6} \\ \text { Uridine triphosphate } & 40 & 45\end{array}$

* Expressed as $\frac{\text { Phosphate release from nucleotide }}{\text { Phosphate release from ATP under identical conditions }} \times 100 \%$.

The cell-wall membrane preparations also hydrolysed condensed inorganic phosphates. Pyrophosphate was hydrolysed at the same rate as ATP under the same conditions; tripolyphosphate and tetrametaphosphate were hydrolysed slowly; hexametaphosphate was attacked at significant rates (Table 4).

The reversibility of the reaction was tested by incubating the cell-wall membranes with ATP and ADP in the presence of $\boldsymbol{P}_{i}$ or $\mathrm{AT}^{32} \mathrm{P}$. The nucleotides and inorganic phosphate were separated by paper chromatography and the activity of each was found. When the cell-wall membrane was incubated with inorganic radioactive orthophosphate, only the phosphate spot was labelled on the chromatogram; no exchange had taken place. There was no increase of activity in the ADP spot when cell-wall membrane preparations were incubated with $\mathbf{A T}^{32} \mathrm{P}$; the bulk of the activity appeared in the orthophosphate. There was thus no indication of reversibility of the hydrolysis of ATP by these cell-wall membrane preparations.

$\mathrm{AT}^{32} \mathrm{P}$ was also incubated with other nucleotides and their activity measured after separation by paper chromatography. Consistent labelling was found in uridine triphosphate and cytidine triphosphate only. The amount of ${ }^{32} \mathrm{P}$ incorporated 
represented only $1 \%$ of that added as $\mathrm{AT}^{32} \mathrm{P}$ but the specific activity, although not measured, appeared to be high.

Inhibition of the ATPase. 2,4-Dinitrophenol decreased the inhibition of the rate of hydrolysis by excess ATP and at high concentrations of DNP (4 mv) appeared to activate the ATPase. Chloramphenicol had a similar effect. There was no apparent stimulation at concentrations of ATP which did not inhibit.

Table 4. The hydrolysis of inorganic phosphate anhydrides by cell-wall membrane preparations from Lactobacillus arabinosus $17-5$

Tubes contained various amounts of the phosphate anhydrides or of ATP and $\mathbf{M g C l}_{2}$ at the same concentrations; about $20 \mathrm{mg}$. wet wt. of cell-wall membrane. At the two highest concentrations of ATP, $0.5 \mathrm{ml}$. of tris maleate + buffer ( $\mathrm{pH} 7$ ) was in a total volume of $1.5 \mathrm{ml}$.: at the other concentrations of ATP, total volume was $1 \mathrm{ml}$. Where the time and concentration of ATP is the same as that of a phosphate compound, the two incubations were carried out at the same time. Controls for the phosphate content of the compounds and the cell-wall membrane have been deducted as usual.

\begin{tabular}{|c|c|c|c|c|}
\hline Substance & $\begin{array}{c}\text { Final } \\
\text { concentration } \\
(\mu \text { mole } / \mathrm{ml} .)\end{array}$ & $\begin{array}{c}\text { Time of } \\
\text { incubation } \\
\text { (hr) }\end{array}$ & $\begin{array}{c}\text { Release } \\
(\mu \text { mole P/g. } \\
\text { dry wt./hr })\end{array}$ & $\begin{array}{l}\text { Hydrolysis } \\
\text { of phosphate } \\
\text { compound } \\
(\%)\end{array}$ \\
\hline ATP & $\begin{array}{l}2 \\
2 \\
2 \\
3 \cdot 75 \\
15\end{array}$ & $\begin{array}{c}0 \cdot 33 \\
1 \\
2 \\
1 \\
1\end{array}$ & $\begin{array}{r}1480 \\
250 \\
240 \\
735 \\
2570\end{array}$ & $\begin{array}{r}62 \\
55 \\
107 \\
65 \\
57\end{array}$ \\
\hline $\mathrm{Na}_{4} \mathbf{P}_{2} \mathrm{O}_{7}$ & $\begin{array}{l}2 \\
2 \\
2 \\
3 \cdot 75 \\
15\end{array}$ & $\begin{array}{l}0 \cdot 33 \\
1 \\
2 \\
1 \\
1\end{array}$ & $\begin{array}{l}623 \\
477 \\
261 \\
855 \\
113\end{array}$ & $\begin{array}{r}13 \\
53 \\
58 \\
42 \\
1\end{array}$ \\
\hline $\mathrm{Na}_{5} \mathbf{P}_{\mathbf{3}} \mathrm{O}_{10}$ & $\begin{array}{l}\mathbf{2} \\
\mathbf{2} \\
\mathbf{2}\end{array}$ & $\begin{array}{l}\mathbf{0} \cdot \mathbf{3 3} \\
\mathbf{1} \\
\mathbf{2}\end{array}$ & $\begin{array}{l}\mathbf{0} \\
\mathbf{7 \cdot 2} \\
\mathbf{5} \cdot \mathbf{0}\end{array}$ & $\begin{array}{r}0 \\
16 \\
22\end{array}$ \\
\hline$\left(\mathrm{NaPO}_{3}\right)_{4}$ & $\begin{array}{l}2 \\
2 \\
2\end{array}$ & $\begin{array}{l}\mathbf{0} \cdot \mathbf{3 3} \\
\mathbf{1} \\
\mathbf{2}\end{array}$ & $\begin{array}{r}0 \\
10 \cdot 8 \\
3 \cdot 0\end{array}$ & $\begin{array}{r}0 \\
18 \\
13\end{array}$ \\
\hline$\left(\mathrm{NaPO}_{3}\right)_{6}$ & $\begin{array}{l}2 \\
2 \\
2\end{array}$ & $\begin{array}{l}\mathbf{0} \cdot \mathbf{3 3} \\
\mathbf{1} \\
\mathbf{2}\end{array}$ & $\begin{array}{r}0 \\
\mathbf{5 2 7} \\
\mathbf{3 6 2}\end{array}$ & $\begin{array}{r}0 \\
117 \\
181\end{array}$ \\
\hline
\end{tabular}

Oligomycin and ouabain had no effect on the hydrolysis of ATP by the cell-wall membrane at $10 \mu \mathrm{g}$. dry wt. $/ \mathrm{ml}$. These concentrations were sufficient to inhibit the $\mathrm{Na}^{+}$stimulated and $\mathrm{K}^{+}$stimulated brain ATPases almost completely.

The effects of the sulphydryl-blocking reagents phenylmercuriacetate and $p$-chloromercuribenzoate were complicated. Further inhibition was found at some concentrations of ATP which were alone sufficient to cause inhibition of the ATPase. At a higher concentration of ATP there was apparent stimulation (Table 5). Sodium deoxycholate had similar effects to those of sulphydryl-blocking agents. Hexadecyltrimethylammonium bromide (Cetavlon) had no effect on the ATPase at or below $0.1 \mathrm{~mm}$. At $1 \mathrm{~mm}$, that is, above the critical point of micelle formation, the phosphate release decreased to $10-20 \%$ of its normal value. This inhibitory concentration was a hundred times that required to prevent growth of the Lactobacillus arabinosus strain used. Ammonium sulphate had an inhibitory effect at high concentrations. Fluoride $(5 \mathrm{~mm})$ inhibited the enzyme strongly over all concentrations of ATP tested. 
Ultrasonic treatment of the cell-wall membrane. Treatment of suspensions of cellwall membrane preparations in the MSE Mullard cell disintegrator released various amounts of ATPase and comminuted the membranes into increasingly finer fragments (Pl. 1, fig. 3), depending on the time of treatment. After centrifugation at $100,000 \mathrm{~g}$ for $2 \mathrm{hr}$ of a preparation treated ultrasonically for $45 \mathrm{~min}$. the supernatant fluid, although clear, was enzymically active (Table 6). The solid deposit and the supernatant fluid both showed about a threefold increase in their maximum

Table 5. The effect of phenylmercuriacetate (PMA) and p-chloromercuribenzoate $(C M B)$ on phosphate release from ATP by cell-wall membrane preparations

Tubes contained various amounts of ATP; cell-wall membrane (15 mg. wet wt.); $\mathrm{Mg}^{2+}$ at the same concentration as ATP; $0.5 \mathrm{ml}$. 0.1 M tris + maleate buffer (pH 7); 0.75 mmole mercury compound in a final volume of $1.5 \mathrm{ml}$. The tubes were incubated at $37^{\circ}$ for $45 \mathrm{~min}$., after which the phosphate release was estimated in the usual way.

\begin{tabular}{|c|c|c|c|}
\hline \multirow{3}{*}{$\begin{array}{l}\text { ATP alone } \\
\text { ATP + PMA }\end{array}$} & $\begin{array}{l}(\mathbf{3} \cdot 3) \\
\mathbf{P} \text { rele }\end{array}$ & $\begin{array}{r}\text { conc. } \\
(6 \cdot 7) \\
\text { e P/g. } \\
\text { brane }\end{array}$ & $\begin{array}{c}\text { (13) } \\
\text { ll-wall }\end{array}$ \\
\hline & 2760 & 4120 & 760 \\
\hline & 2140 & 3600 & 2350 \\
\hline $\mathbf{A T P}+\mathbf{C M B}$ & 2020 & 3540 & 3260 \\
\hline
\end{tabular}

Table 6. The effect of various concentrations of ATP on ultrasonically treated cellwall membrane of Lactobacillus arabinosus $17-5$ and its supernatant fluid

Tubes contained different concentrations of ATP; ultrasonically treated cell-wall membrane $(20 \mathrm{mg}$. wet wt.) or the corresponding $100,000 \mathrm{~g}$ supernatant fluid (equiv. $4 \mathrm{mg}$. dry wt.); $\mathrm{Mg}^{2+}$ at the same concentration as ATP; $0.5 \mathrm{ml}$. of $0.1 \mathrm{M}$-tris + maleate buffer ( $\mathrm{pH} 7$ ) in a total volume of $1.5 \mathrm{ml}$. After incubation for $30 \mathrm{~min}$. at $37^{\circ}$ phosphate release was estimated in the usual way.

$\begin{array}{ccc} & \begin{array}{c}\text { Phosphate release by } \mu \text { mole } \\ \text { P/g. dry wt./hr. }\end{array} \\ \text { Conc. of ATP } & \begin{array}{c}\text { ultrasonically } \\ \text { treated cell-wall }\end{array} & \begin{array}{c}100,000 \mathrm{~g} \\ \text { supernatant }\end{array} \\ (\mathrm{mM}) & \text { membranes } & \text { fluid } \\ 3 \cdot 3 & 14,700 & 15,100 \\ 6 \cdot 7 & 20,600 & 16,900 \\ 13 \cdot 3 & 2380 & 1110\end{array}$

specific activity. The value of $K_{m}$ for the supernatant fluid was $0.6 \mathrm{~mm}$. In other properties the ATPase in the supernatant fluid appeared very similar to that in the untreated cell-wall membrane preparation. This included the inhibitory effects of high concentrations of ATP, and the effect of 2,4-dinitrophenol. Further centrifugation of this supernatant fluid for $16 \mathrm{hr}$ at $100,000 \mathrm{~g}$ did not yield a solid pellet, nor distinct layering. The supernatant fluid was separated into upper, middle and bottom fractions. The bottom fraction was considerably enriched in both protein and enzymic activity ('Table 7 ). The addition of ammonium sulphate up to $80 \%$ saturation of the clear $100,000 \mathrm{~g}$ supernatant fluid precipitated the bulk of the enzyme activity. The first precipitate, up to $50 \%$ saturation with ammonium sulphate would not redissolve in water or various buffers; the other fractions did resuspend to give clear liquids. There was no increase in specific activity in any fraction obtained by this treatment. 
The effect of enzymes on ATPase activity. Cell-wall membrane preparations were incubated with various hydrolytic enzymes at values between $\mathrm{pH} 5$ and 8 . After incubation the particulate material was removed by centrifugation and the ATPase of this deposit and the supernatant fluid compared with controls incubated without the addition of enzymes (Table 8). In most cases there was a marked decrease of ATPase activity, except in the case of material digested with pancreatic lipase where there was a marked increase in activity in the supernatant fluid but no decrease of

Table 7. The protein and ATPase distribution after the long centrifugation of the $100,000 \mathrm{~g}$ supernatant fluid of the ultrasonically treated cell-wall membranes of Lactobacillus arabinosus $7-5$

Protein determination was by the usual method. For the ATPase determination, tubes contained ATP and $\mathrm{Mg}^{2+}(8.4 \mathrm{mM})$; a fraction of the supernatant fluid (0.2 $\left.\mathrm{ml}.\right)$; $0.5 \mathrm{ml}$. of $0.1 \mathrm{M}$-tris + maleate buffer $(\mathrm{pH} 7$ ) in a total volume of $1.3 \mathrm{ml}$. After incubation for $3 \mathrm{~min}$. at $37^{\circ}$, phosphate release was estimated in the usual way. The figures are not corrected for the negligible phosphate content of the supernatant fractions.

\begin{tabular}{|c|c|c|}
\hline $\begin{array}{l}\text { Layer of supernatant } \\
\text { fluid }\end{array}$ & $\begin{array}{l}\text { Phosphate release } \\
\text { ( } \mu \text { mole P/ml./hr) }\end{array}$ & $\begin{array}{l}\text { Protein content } \\
\text { (mg./ml.) }\end{array}$ \\
\hline $\begin{array}{l}\text { Lower } \\
\text { Middle }\end{array}$ & $\begin{array}{r}19 \cdot 6 \\
1 \cdot 8\end{array}$ & $\begin{array}{r}16 \cdot 5 \\
4 \cdot 5\end{array}$ \\
\hline Upper & $1 \cdot 3$ & $4 \cdot 3$ \\
\hline
\end{tabular}

Table 8. The effect on the cell-wall membrane preparations from Lactobacillus arabinosus 17-5 of incubation with various enzymes

Cell-wall membranes (50 mg. wet wt.) were incubated with about $1 \mathrm{mg}$. of the enzymes shown for $1.5 \mathrm{hr}$ at $37^{\circ}$ in buffer of the shown $\mathrm{pH}$ value. After centrifugation at $10,000 \mathrm{~g}$ for 5 min., the supernatant fluid was separated from the solid cell-wall membrane and both fractions were tested for ATPase activity. A control tube was incubated containing no external enzyme at $\mathrm{pH} 7$. These fractions were then incubated with 3 mu ATP and $\mathrm{Mg}^{2+}$ and $0.5 \mathrm{ml} .0 \cdot 1 \mathrm{M}$-tris + maleate buffer $\left(\mathrm{pH} 7\right.$ ) in a total volume of $1 \mathrm{ml}$, , for $45 \mathrm{~min}$. at $37^{\circ}$. Phosphate release was then estimated in the usual way. Blanks were run as usual for the phosphate content of the ATP and the incubated fractions. Phosphate release is expressed as a percentage of the untreated control.

\begin{tabular}{lccc}
\multicolumn{1}{c}{ Enzyme } & $\begin{array}{c}\text { pH value of } \\
\text { incubation } \\
\text { mixture }\end{array}$ & $\begin{array}{c}\text { Supernatant } \\
\text { fraction }\end{array}$ & $\begin{array}{c}\text { Cell-wall } \\
\text { membrane } \\
\text { fraction }\end{array}$ \\
Papain & $\mathbf{6}$ & $\mathbf{1 4}$ & 49 \\
Hyaluronidase & $\mathbf{5}$ & $\mathbf{1 9}$ & $\mathbf{3 0}$ \\
Mycozyme & $\mathbf{7}$ & $\mathbf{3 8}$ & $\mathbf{4 4}$ \\
Lysozyme & $\mathbf{7}$ & $\mathbf{9 4}$ & $\mathbf{1 0 7}$ \\
Trypsin & $\mathbf{8}$ & $\mathbf{1 1}$ & $\mathbf{1 4}$ \\
Rattlesnake venom & $\mathbf{7}$ & $\mathbf{5 1}$ & $\mathbf{3 3}$ \\
Phospholipase D + Ca ${ }^{2+}$ & 8 & $\mathbf{5 1 0}$ & $\mathbf{6 2}$ \\
Lipase (pancreatic) & $\mathbf{8}$ & & $\mathbf{9 2}$
\end{tabular}

activity in the solid deposit. It is possible that this result indicates a release of ATPase activity accompanied by an activation of the released enzyme. As with the preparations partially solubilized by ultrasonic treatment, it was not found possible to fractionate further the enzyme released by lipase by the usual precipitation methods.

Chemical composition of cell-rvall membrane. The cell-wall membranes contained 
$\mathbf{2 0 - 2 3} \%$ protein compared to $\mathbf{2 7 - 3 0} \%$ present in the whole bacteria (calculated on dry wt.). The total lipid varied from 7 to $11 \%$ and represented the bulk of that contained in the bacteria; that remaining in the supernatant fluid was separable by further centrifugation. The lipid after extraction contained about $4 \%$ phosphorus and can thus be assumed to be mainly phospholipid. Methyl esters of the fatty acids were prepared after saponification and examined by gas chromatography. There was no significant difference in the carbon number of the fatty acids from whole bacteria, cell-wall membrane or the supernatant fluid fractions. The bulk of the acids had carbon numbers between $\mathrm{C}_{15}$ and $\mathrm{C}_{18}$, but were not examined in detail. The total carbohydrate content of the cell-wall membranes was $37 \%$ compared to $14 \%$ of the whole bacteria. The glucosamine determinations in whole bacteria were not very consistent, but the carbohydrate of the supernatant fluid contained about $0.8 \%$ glucosamine while that of the cell-wall membranes contained $2 \cdot 4 \%$. Both supernatant fluid and cell-wall membranes contained considerable amounts of rhamnose which is often used as an indication of the presence of bacterial cell-walls; cell-wall membranes contained 9-12\% rhamnose. The DNA content of the cell-wall membranes was usually negligible, but some batches contained up to $0.8 \%$; this amount when present was usually associated with electron-dense granules trapped in relatively unfragmented cell-wall membranes. The RNA content of the cell-wall membranes was $7 \%$ when DNA was mostly absent, but increased when the DNA content was higher and was presumably due to the trapping of cytoplasmic contents. The chemical analysis of fragments of cell-wall membrane isolated after ultrasonic treatment was substantially the same as that of the intact cell-wall membranes. A preliminary examination by paper chromatography of the amino acids obtained by acid hydrolysis of cell-wall membrane showed the complete range of typical proteins. The chemical analysis therefore confirms the idea that a large part of the cytoplasmic membrane is present together with the cell wall in these preparations.

Cellular distribution of enzymes other than ATPase. Supernatant and cell-wall membrane fractions were examined in some detail for the presence of the riboflavinmediated oxidation of pyruvate, lactate and glycerophosphate, glucose and glycerol (Strittmatter, 1959). Oxygen uptake with these substrates by the fractions was measured manometrically in the Warburg apparatus, with and without methylene blue and riboflavin. In all cases the enzymic activity was in the supernatant fractions and the cell-wall membrane was without significant activity. The activity in the supernatant fractions was not removed by centrifugation at $25,000 \mathrm{~g}$ for periods up to $2 \mathrm{hr}$. Similar results were obtained with supernatant fractions from bacteria broken in a 'sonomec' shaker (Rodgers \& Hughes, 1960) or by ultrasonic treatment for $15 \mathrm{~min}$. There was some pyruvate oxidase in the solid fractions from bacteria treated ultrasonically for longer periods (up to $60 \mathrm{~min}$ ). This is similar to the findings of Strittmatter who disintegrated bacteria in the Raytheon disintegrator for $60 \mathrm{~min}$., and was possibly due to denaturation of soluble protein (Hughes, 1961). Other enzymes found in the supernatant fraction and not in the cell-wall membranes were hexokinase, myokinase and malic enzyme. Enzymes located in the supernatant fractions in previous work include nicotinamide deamidase (Hughes \& Williamson, 1953), pantothenate and pantothine phosphorylase (Pierpoint, Hughes, Baddiley \& Mathias, 1955), cytidine pyrophosphorylase (Shaw 1961), lactic dehydrogenase (Don \& Kaplan, 1960). It is also likely that most, if 
not all, of the glycolytic enzyme system is soluble (Hughes, 1951). None of the cellwall membrane preparations had polynucleotide phosphorylase activity when tested by the method of Abrams \& McNamara (1962).

\section{DISCUSSION}

The outer shell or hull of Lactobacillus arabinosus strain 17-5 has been prepared by crushing the bacteria in the Hughes press and removing the cytoplasmic contents by washing. Such preparations formed inorganic phosphate from ATP at rates of 1.0-6 mmole P/g. dry wt./hr. Phosphate was also released from ADP at slower rates and kinetic evidence suggests that the same enzyme was involved in both reactions. There was also a phosphate release from various inorganic phosphates but it was not certain whether this too was due to the nucleotide phosphatase which hydrolysed ATP and ADP as follows: ATP $+\mathrm{H}_{2} \mathrm{O} \rightarrow \mathrm{ADP}+\mathrm{H}_{3} \mathbf{P O}_{4}$. It is noteworthy that so far this is the only enzymic activity definitely associated with outer shells of $L$. arabinosus, whereas similar preparations from obligate and facultative aerobes contain a wide range of enzymes associated with energy production and electron transport (Hughes, 1962). The cell-wall membranes from a wide range of aerobically grown bacteria have also been found to have an ATPase similar to that reported here, and the enzyme has also been found in membrane preparations from Streptococcus faecalis (Abrams, McNamara \& Johnson, 1960) and in preparations from $L$. casei supplied to us by Dr J. Shockman. More recently the enzyme has been found in cell-wall membranes and empty spheroplasts ('ghosts') of Clostridium sporogenes (Galli \& Hughes, 1965) and in particulate fractions of Chlorobium thiosulphatophilum (Cole \& Hughes, 1965). The hull preparations from $L$. arabinosus contained from 7 to $11 \%$ total lipid of which the bulk appeared to be phospholipid since it contained about $4 \%$ phosphorus. Most of the fatty acids previously reported to be present in this organism (Hofman, Lucas \& Sax, 1952) appeared to be present in this hull lipid. A variable amount of ATPase activity was found in the supernatant fractions after centrifugal deposition of 'hulls', but the bulk of this could be recovered as a solid pellet by more prolonged centrifugation. This pellet also contained lipid and carbohydrate in about the same proportion as in the 'hulls' and it is assumed to be the result of their further comminution during disintegration; similar fragments were obtained by ultrasonic treatment. Up to now no satisfactory method has been found for solubilizing the ATPase of these hulls or of markedly increasing its specific activity. Of a number of enzymes, only pancreatic lipase brought about a release of some part of the enzymic activity from the particulate preparations, but this released enzyme could be regarded as insoluble since it was concentrated by centrifugation. The evidence therefore strongly supports the idea that the ATPase is bound to the protoplasmic membrane and that the membrane or large parts of it are associated with the wall in these preparations. They have therefore been assumed to be similar to cell-wall membranes previously described (Hughes, 1962). In the whole bacteria the ATPase cannot utilize exogenous ATP, presumably because the latter cannot enter.

Membrane bound ATPases are widely distributed in nature (Novikoff, Essner, Goldfischer \& Heus, 1962) and are associated with ion transport (Whittam, 1964) changes in conformation (Kielly, Kimura \& Cooke, 1964) and energy production 
(Jagendorf, Hind \& Neuman, 1964). The ATPase from Lactobacillus arabinosus differs from those associated with ion transport in that it is not markedly inhibited by ouabain and oligomycin; in experiments not reported here it was not markedly affected by $\mathrm{Na}^{+}$or $\mathrm{K}^{+}$. Its $\mathrm{pH}$ optimum was also markedly lower (pH 6.0) than ATPases associated with ion transport. On the other hand it is stimulated by DNP, as is the ATPase of fragmented mitochondrial christae associated with oxidative phosphorylation.

Experiments with labelled ATP and lactobacillus ATPase preparations did not transfer terminal phosphate to any acceptor added, but the possibility cannot be ruled out that the ATPase is concerned in a phosphorylation associated either with cell-membrane or cell-wall synthesis. The lactobacillus preparations had no nucleotide pyrophosphorylase activity such as reported for membranes of Streptococcus faecalis (Abrams \& McNamara, 1962). The consistent presence of RNA in the preparations of lactobacillus cell-wall membranes however lends support to the many suggestions that some membranes in bacteria play a role in protein synthesis in association with ribosomes or ribosomal RNA (Hunter, Brookes, Crathorn \& Butler, 1959; Nisman \& Fukuhara, 1961). It is possible that this ubiquitous ATPase is also involved. Up to the present however no definite role can be ascribed to this enzyme.

Thanks are due to the Rockefeller Foundation, National Institutes of Health and United States Air Force for grants to the Department. Thanks are also due to Dr J. Wimpenny for helpful discussions and to Miss H. Volman and Miss A. West for skilled assistance.

\section{REFERENCES}

Abrams, A. \& McNamara, P. (1962). Polynucleotide phosphorylase in isolated bacterial cell membranes. J. biol. Chem. 237, 170.

Abrams, A., McNamara, P. \& Johnson, F. B. (1960). Adenosine triphosphate in isolated bacterial cell membranes. J. biol. Chem. 235, 3659.

Aminoff, D., Morgan, W. T. J. \& Watkins, W. M. (1951). Immunochemistry. XI. Action of dilute alkali on the $\mathrm{N}$-acetylhexosamines and the specific blood group mucoids. Biochem. J. 51, 379.

Barton-Wright, E. C. (1952). The Microbiological Assay of the Vitamin B Complex and Amino Acids. London: Ed. Pitman and Sons.

Burton, K. (1956). A study of the conditions and mechanism of the diphenylamine reaction for the colorimetric estimation of deoxyribonucleic acid. Biochem. J. 62, 315.

Chernick, S. S., Chaikoff, I. L. \& Abraham, S. (1951). Localities of initial block in glucose metabolism in diabetic liver slices. J. biol. Chem. 193, 793.

Cole, J. A. \& Hughes, D. E. (1965). The metabolism of polyphosphates in Chlorobium thiosulphatophilum. J. gen. Microbiol. 38, 65.

Dische, A. (1929). A new characteristic colour reaction for thymonucleic acid. Biochem. J. 204, 431 .

Dische, Z. \& Shetrues, L. B. (1948). A specific colour reaction of methylpentoses and a spectrophotometric micro method for their determination. J. biol. Chem. 175, 595.

Don, D. \& KaPLAN, N. O. (1960). D \& L lactic dehydrogenases in Lb. plantarum. J. biol. Chem. 235, 810.

Fiske, C. H. \& SubbaRow, Y. (1925). The colorimetric determination of phosphorus. J. biol. Chem. 66, 375.

Francis, M. J. O., Hughes, D. E., Kornberg, H. L. \& Phizackerly, P. J. R. (1963). The oxidation of L-malate by Pseudomonas sp. Biochem. J. 89, 430.

Galli, E. \& Hughes, D. E. (1965). Studies on the autolysis of Clostridium sporogenes. J. gen. Microbiol. 
Glynn, I. M. \& Chappeli, J. B. (1964). A simple method for the preparation of ${ }^{32} \mathrm{P}$ labelled adenosine triphosphate of high specific activity. Biochem. J. 90, 147.

Hofman, K., Lucas, R. A. \& SAx, S. M. (1952). Chemical nature of the fatty acids of Lactobacillus arabinosus. J. biol. Chem. 195, 473.

Hughes, D. E. (1951). A press for disrupting bacteria and other microorganisms. Brit. J. exp. Path. 32, 97.

Hughes, D. E. (1961). The disintegration of bacteria and other microorganisms by the M.S.E.-Mullard ultrasonic disintegrator. J. Biochem. Microbiol. Technol. Eng. 3, 405.

Hughes, D. E. (1962). The bacterial cytoplasmic membrane. J. gen. Microbiol. 29, 39.

Hughes, D. E. \& Wrlliamson, D. H. (1953). The deamination of nicotinamide by bacteria. Biochem. J. 55, 851 .

Hunter, G. D., Brookes, P., Crathorn, A. R. \& Butler, J. A. V. (1959). Intermediate reactions in protein synthesis by the isolated cytoplasmic-membrane fraction of Bacillus megaterium. Biochem. J. 73, 369.

JaGendorf, A. T., Hind, G. \& Neuman, J. (1964). An intermediate in photophosphorylation. 6th int. Congr. Biochem. Abstr. 10, 752.

Kielly, W. W., Kimura, M. \& Cooke, J. P. (1964). The active site of myosin. 6th int. Congr. Biochem. Abstr. 13, 634.

Kouleman, A. I. M. (1957). Gas Chromatography. New York: Rheinhold Publishing Corp.

Krebs, H. A. \& Hems, R. (1953). Some reactions of adenosine and inosine phosphates in animal tissues. Biochim. biophys. Acta, 12, 172.

Levvy, G. A. \& McAllen, A. (1959). N-Acetylation and estimation of hexosamines. Biochem. J. 73, 127.

Lowry, O. H., Rosebrough, N. J., Farr, A. L. \& Randall, R. J. (1951). Protein measurement with the folin phenol reagent. J. biol. Chem. 193, 265.

Mejbaum, W. (1939). Über die Bestimmung kleiner Pentose Mengen, insbesondere in Derivaten der Adenylsäure. Z. physiol. Chem. 258, 117.

Milner, H. W., Lawrence, N. S. \& French, C. S. (1950). Disintegration of bacteria and small particles by high-pressure extension. Science, 111, 633.

Nrsman, B. \& Fukuhara, H. (1961). Amino acid activation and incorporation, $\beta$-galactosidase synthesis by subcellular fractions obtained from digitonin lysed protoplasts. Prog. Biophys. biophys. Chem. 11, 252.

Novikoff, A. B., Essner, E., Goldfischer, S. \& Heus, M. (1962). Nucleoside phosphatase activities of cytomembranes. Symp. int. Soc. Cell Biol. 1, 149-92.

Partridge, S. M. \& Westall, R. G. (1948). Filter paper partition chromatography of sugars. I. General description and application to the qualitative analysis of sugars in apple juice, egg white, and foetal blood of sheep. Biochem. J. 42, 238.

Pierpoint, W. S., Hughes, D. E., Baddiley, J. \& Mathias, A. P. (1955). The phosphorylation of pantothenic acid by Lactobacillus arabinosus 17-5. Biochem. J. $61,368$.

Putman, E. W. (1957). Meth. Enzymol. 3.

Renshaw, A. \& Biran, L. A. (1962). A method for the introduction of samples of long chain fatty methyl esters on to gas chromatography columns. J. Chromatography, 8, 343.

Rodgers, A. \& Hughes, D. E. (1960). The disintegration of microorganisms by shaking with glass beads. J. biochem. microbiol. Technol. Engng. 2, 49.

Shaw, D. R. D. (1961). Pyrophosphorylysis and enzymic synthesis of cytidine diphosphate glycerol and cytidine diphosphate ribitol. Biochem. J. 82, 297.

Strittmatter, C. (1959). Electron transport in Lactobacilli. J. biol. Chem. 234, 2789.

Whitтам, R. (1964). Directionality of membrane-bound enzymes. 6th int. Congr. Biochem. Abstr. 8, 611.

Worwoy, A. J. (1949). Method for the estimation of micro amounts of amino nitrogen and its application to paper partition chromatography. Biochem. J. 45, 412. 


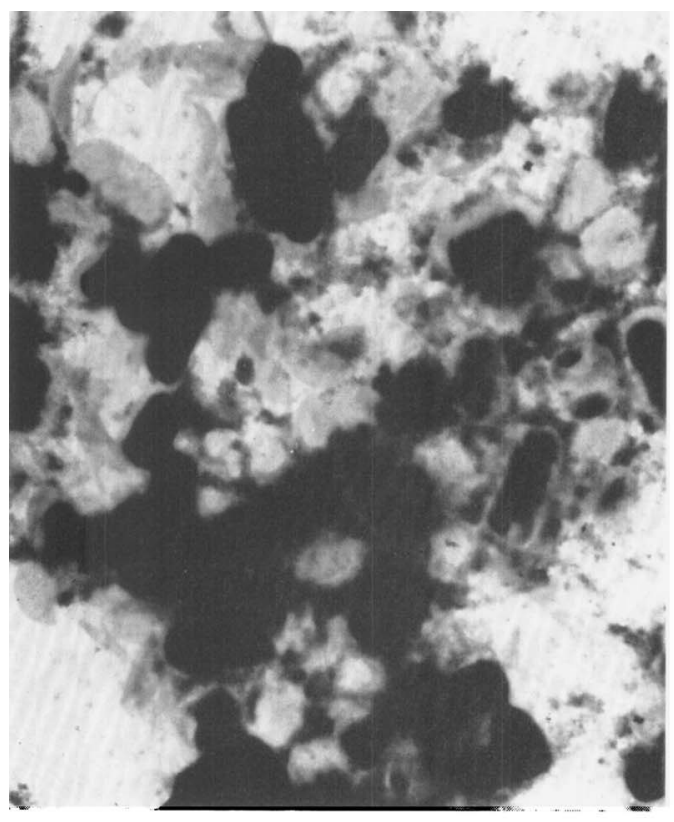

Fig. 1

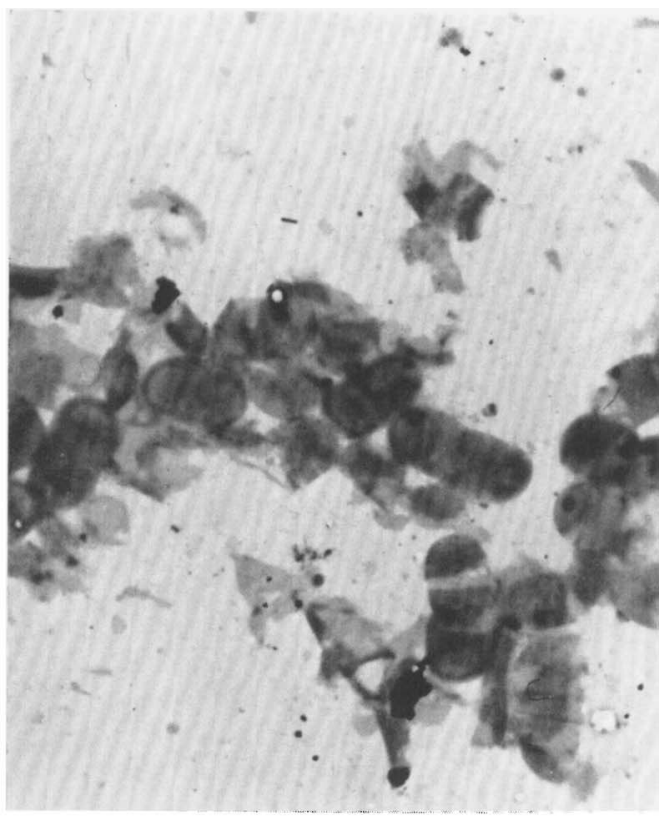

Fig. 2

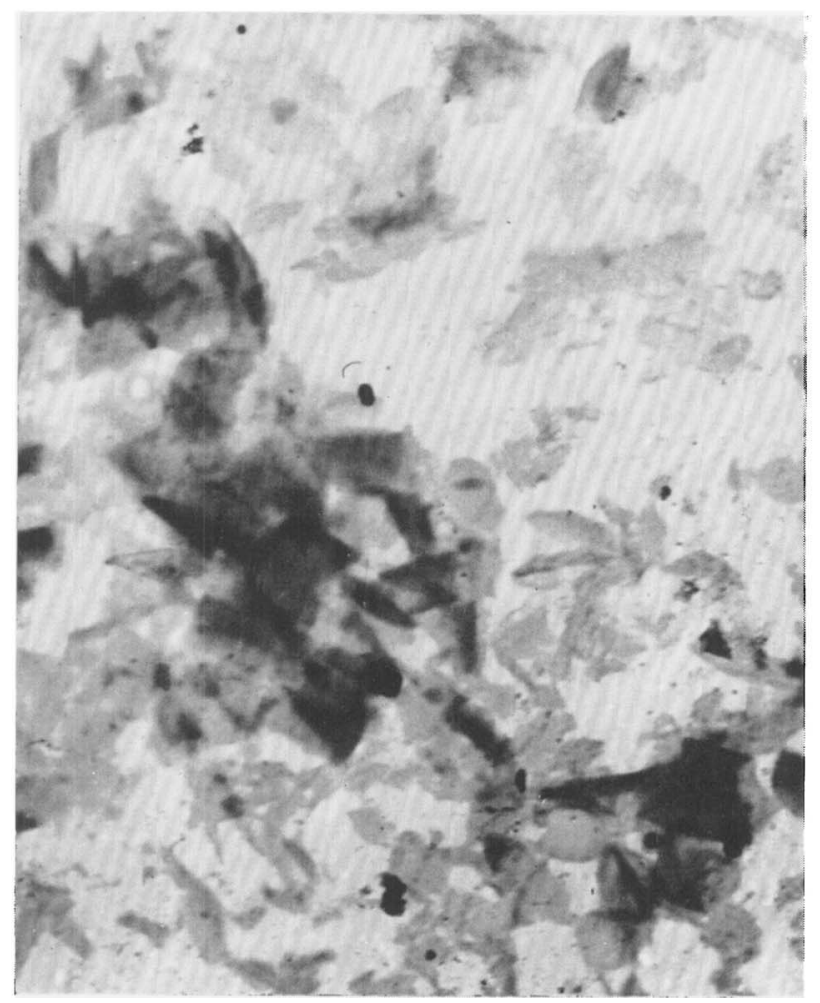

Fig. 3 


\section{EXPLANATION OF PLATE}

Fig. 1. Disintegrated Lactobacillus arabinosus 17-5 before fractionation by centrifugation. Bacteria were disintegrated by crushing in the Hughes press and treated with DNAase, fixed and mounted for examination without further treatment. $\times 6500$.

Fig. 2. Cell-wall membranes from Lactobacillus arabinosus 17-5 after purification. The disintegrated bacteria shown in fig. 1 were fractionated by centrifugation as described in the text. $\times 6500$.

Fig. 3. Cell-wall membranes of Lactobacillus arabinosus 17-5 after ultrasonic treatment. A purified preparation of cell-wall membranes was treated for 10 min. in the M.S.E. cell disintegrator, fixed and mounted as before. $\times 8500$. 